\title{
Generic Structure Potential Analysis of Feature Articles in Nigerian Newspapers
}

\author{
Adesina B. Sunday \& Olufunke O. Fagunleka \\ http://dx.doi./org/10.4314/ujah.v18i1.6
}

\section{Abstract}

This paper investigated the generic structure potential of feature articles in four Nigerian newspapers: The Punch, The Nation, Vanguard and Nigerian Tribune. Halliday and Hassan's concept of Generic Structure Potential served as the theoretical framework. The feature articles analysed had three obligatory elements: Headline, Orientation and Addressing the Issue, and three optional elements: Feature Lead, Proffering a Solution and Moral Lesson. A Nigerian newspaper feature article typically starts with a headline that may or may not be followed by a feature lead. This is followed by an orientation, an issue to be addressed, which is then followed by either a suggested solution or a moral lesson. The study posited that the GSP of feature articles in Nigerian newspapers can be catalogued as $H^{\wedge} \quad[(F L)$ $\left.{ }^{\wedge} O^{\wedge}\right]\left[A I^{\wedge}(P S) .(M L).\right]$.

\section{Introduction}

The media is a veritable means of disseminating information around the world. Its effectiveness and speed provide an important platform for either constructive or negative contributions that can bring or hinder development in every facet of life (Afful, 2012). The media refer to institutions that deal with the packaging and disseminating information to the public. Broadly, there are two categories of the media - the electronic and the print media. The 
print media comprises newspapers and magazines that are printed for mass readership, while the electronic media comprises radio and television and involves the transmission of sound or images through air waves, cable or satellite. In Nigeria, the radio is the key source of information for many people. This is because it is easily accessible both in the cities and villages and most of the programmes are in local languages. Many Nigerians also depend on newspapers for information that has to do with Nigeria and other parts of the world.

A newspaper is a publication that appears regularly and frequently and carries news about a wide variety of current events. The term is commonly used to refer to daily or weekly publications that bring news of general interest to large portions of the public in a specific geographic area. Human beings exchanged news long before they could write. They spread news by word of mouth on crossroads, at campfires or at markets. Messengers raced back from battlefields with reports on victories or defeats. Criers walked through villages announcing births, deaths, marriages and divorces (Stephens, 1994).

Newspapers inform readers of current events; they also entertain, teach or create humour by dedicating some sections to a form of storytelling, which is referred to as feature or feature story. The news profession has always identified two clear genres, each with its own subject matter and rules of composition; as a result, news is usually demarcated into two categories: "hard news" and "soft news or features". A typical newsroom can thus be described as a world of "hard news" and "soft news/feature stories" (Bula, 1996). These two major genres assign significantly different writing styles and story structures to different topics. What drives the two forms is the nature of the subject being focused on. The hard news focuses on the discrete events, statements, decisions, 
actions and disasters. The soft news, also known as features, places emphasis on the other dimensions of life, such as explanation, history, thought, feeling, mood and process (Bula, 1996). Daily newspapers employ the two major writing genres to present their information to the readers.

The soft news or feature stories have become more important in contemporary newspapers - their contents appeal more to readers than the average news reports because of the human interest approach that this newspaper sub-genre employs. As a result, more newspapers are beginning to shift focus in this direction, as newspaper feature stories are no longer restricted to weekend editions, but also appear in the daily editions. Feature journalism is becoming increasingly important for newspapers. This is because competition from online news sites has brought about a decrease in newspaper circulation worldwide, thus decreasing the value of newspapers. The addition of more feature stories is seen as a possible solution for the struggling newspaper industry (Steensen, 2009).

Feature articles are descriptive and reflective writing about original ideas. Compared with straight news, a feature article requires more creative energy, is less objective, informative, and is always entertaining (Garrison, 2004). The communicative purpose of feature articles is to entertain and connect people on an emotional level through accounts of personal experiences of perceived public value; thus, they are usually emotional, involving the readers. Feature stories often portray people, as well as physical and social conditions and events (Steensen, 2010) through the use of various rhetorical devices. Feature writers have the liberty of writing in a subjective style, thereby sharing a kind of intimacy with the audience (Steensen, 2009). Features can be about any subject from simple lifestyle issues to tough and complex 
issues. They are usually written with a personal tone through the use of informal, colloquial and first-person narrative. Relevant jargons, rhetorical questions and emotive words are used to authenticate the information and opinions and to evoke a personal response in the reader.

Previous studies have dwelt extensively on the hard news and editorial genres (Bolivar, 1994; Ansary and Babaii, 2004; Ogungbe, 2012) but little attention has been paid to the feature article genre. Also, some studies have applied the GSP approach to a number of discourses in the mass media in order to establish their generic structures. They include business letters (Ghadessy, 1993), newspaper editorials (Ansary and Babaii, 2004), newspaper editorials and learner's comprehension (Shoukouhi and Amin 2010), and magazine editorials (Odebunmi, 2007).Therefore, this paper studied the feature article in order to find out its generic structure and the way rhetorical strategies are employed in this particular discourse in Nigerian newspapers.

\section{Theoretical Framework}

This study was premised on the theory of genre analysis, an aspect of Systemic Functional Linguistics (SFL), as proposed by Halliday and Hasan (1985). Part of the focus of SFL is the identification of recurring patterns that are used in the organization of the content of a specific genre and the relationship between these patterns and specific linguistic features (Halliday and Hasan, 1989; Henry and Roseberry, 1997; Ansary and Babaii, 2004; 2009; Bruce, 2009).

Genre, according to the social application of language, is a class of communicative event, which comprises "... not only the discourse itself and its participants, but also the role of that discourse and the environment of its production and reception, including its historical and cultural association" (Swales, 1990:46). 
Communicative events are usually determined by communicative purposes, which often vary, such that, in a particular discourse community, we can find different kinds of genres (Swales, 1990). Genre is defined by Halliday and Hasan (1985) as a meaning which results from language which does a particular job in a particular contextual configuration. The term "genre-specific semantic potential" or "generic structure potential" (GSP) is used to describe a particular type of text which is different from any other. The GSP is an obligatory structure of a particular type of text which can be used to diagnose the genre. Therefore, every genre has its own GSP. However, texts of the same genre may have different optional structures (Halliday and Hasan, 1985). Genre has been categorized under the domain of register in a context of situation (Santosa, 2009). Genres are classified or identified according to the professional or peculiar use of language. There are business genre, medical genre, scientific genre, media genre and so on.

The Generic Structure Potential (GSP) model is associated with Halliday and Hasan (1985). The model is built on the assumption that Contextual Configuration (CC), which is a specific set of the values that are used to specify the field, tenor and mode of a discourse, "permits statements about the text structures" to be made (Halliday and Hasan 1985: 56). Specifically, a Contextual Configuration can predict the following about a text structure:

1. Obligatory elements - What elements must occur?

2. Optional elements - What elements may occur?

3. Sequencing of elements - What arrangements of elements are obligatory and optional?

4. Recursiveness - How often may what elements occur? It is possible to express the total range of optional and obligatory elements and their order in such a way that we exhaust the 
possibility of text structure for every text that can be appropriate to a particular CC. This possibility is what is known as the structure potential of this genre or its generic structure potential (GSP). In other words, GSP captures the possible characteristics of texts belonging to a particular genre. Halliday and Hasan (1985) identify the obligatory and optional rhetorical elements of shop interaction or service encounter. This is represented as:

[(G). (SI) $\left.{ }^{\wedge}\right]\left[\left(\right.\right.$ SE.) $\left.\left.\left\{\mathbf{S R}^{\wedge} \mathbf{S C}^{\wedge}\right\}{ }^{\wedge} \mathbf{S}^{\wedge}\right\} \mathbf{P}^{\wedge} \mathbf{P C}(\mathbf{F})\right] \quad$ (Halliday and Hasan, 1989:63-65)

The catalogue above can be read thus: any shop transaction in English should contain the following structural elements: Greeting (G), Sale Initiation (SI), Sale Enquiry (SE), Sale Request (SR), Sale Compliance (SC), Sale (S), Purchase (P), Purchase Closure (PC), and Finis (F). The round brackets ( ) in the above GSP indicate optionality of the enclosed elements. Therefore, G, SI, SE, and F are optional; while SR, SC, S, P and PC are obligatory. The dot between elements means "more than one option" in sequence. The square brackets [ ] show restraint on sequence. The braces with a curved arrow indicate that the degree of iteration for elements in the square brackets is equal. That is to say, if SR occurs twice, then SC must also occur twice. Lastly, the caret sign $\left({ }^{\wedge}\right)$ shows sequence (Ansary and Babaii, 2004: 7).

Essentially, Halliday and Hasan (1989) posit that any shop transaction comprises a series of optional and obligatory structural elements sequenced in a specific order. The obligatory elements define the genre to which a text belongs. Without these elements, the text will not be interpreted as belonging to that particular genre. An optional element is one which can occur but is not under obligation to occur. It is possible to state the generic structure of any genre. That is, each text may have a different actual structure 
but each realizes a possibility built into its generic structure potential (Ansary and Babaii, 2004).

\section{Method}

The data for this study consisted of twenty (20) articles collected from four Nigerian newspapers: Nigerian Tribune, The Nation, The Punch, and Vanguard. These dailies were purposively selected for this study because of their wide circulation. Five (5) editions of each of the newspapers from January 2014 to October 2014 were closely examined to determine the GSP of feature articles of Nigerian newspapers. The samples within this period were selected in order to have a corpus of texts on various topics.

There were articles from daily and weekend editions of the newspapers. The four (4) newspapers have feature stories in the weekend editions. However, three (3) of these newspapers present features on particular days during the week: The Punch has a special feature column on Thursdays, Nigerian Tribune on Fridays and Vanguard on Wednesdays. In The Nation, the features are presented in the magazine section of the weekend editions.

\section{Analysis \\ Obligatory and Optional Elements in the Feature Articles}

The three elements that make up the context of culture (field, tenor and mode) help in determining the structure of a particular text or genre. The following elements were identified in the samples that were analysed:

Headline $(H)$ : This element indicates the topic and gives the reader an idea of the issue around which the text is centred. The excerpts below show this: 


\section{Excerpt 1}

Born too soon in hospitals without incubators

(The Punch, Thursday, May 22, 2014:pp. 26-27)

Excerpt 2

At the mercy of vandals

(The Nation, Saturday, October 11, 2014: pp.17-18, 47-48)

Excerpt 3

Beware! Hi-tech robbers on the prowl

(Nigerian Tribune, Sunday, June1, 2014: pp. 13-14)

Excerpt 4

Welcome to Arepo where vandals are kings

(Vanguard, Wednesday, June11, 2014: p. 57.)

Feature Lead (FL): This element comes immediately after the headline. It is intended to capture the reader's attention immediately. It is like a topic sentence that summarises the content of the article in a concise fashion. It shows the focus of the writer on the issue being discussed. It might be written in a sentence or in a number of sentences. The name of the writer of the article is usually embedded in the feature lead. Examples are given below:

Excerpt 5

As the search for the missing Borno school girls attracts global attention, there may be far too many dangers threatening the safety of children across the country.

(The Punch, Saturday, May 10, 2014: pp. 20-21.)

\section{Excerpt 6}

How work nature, distance adversely affect family life The Dangers of abandoning kids to house helps, nannies (The Nation, Saturday, October 25, 2014: pp.17-18, 47-48.) 


\section{Excerpt 7}

In this report, the United Nations' Refugee Agency (UNHCR)'s Integrated Regional Information Network tells a shocking story of the living conditions of the over 15,000 Nigerian refugees in Cameroon.

(Nigerian Tribune, Saturday, October 11, 2014: p.5.) Excerpt 8

The South African connection and the enemies within

(Vanguard, Wednesday, October 15, 2014: pp. 38-39.)

Orientation $(O)$ : This element introduces the issue for discussion and gives background information on the issue. The following excerpts reveal this:

Excerpt 9

One hot Thursday afternoon, Tony Osagie was seen leafing through a newspaper in one of the offices at the domestic wing of the Murtala Mohammed International Airport, Lagos. His laptop computer was placed on the right side of his desk. At another time, he was seen checking his Facebook status. His job description was not particularly challenging, he told this correspondent. The fact is that the changing times in the aviation industry is taking a toll on his career, as he certainly never had the slightest premonition that he could take up a job as an estate agent. The 29-year-old Canada and America-trained pilot holds a Private Pilot Licence and a Boeing 737 Type Rating Certificate. He was at the Lagos airport to attend a meeting of unemployed Nigerian pilots that used to hold on Thursdays.

(The Punch, Thursday, July 31, 2014: p. 26-27.) 
Excerpt 10

Wailing and desperate prayers by relations of the victims of tanker fire pervaded the air at the Burns Unit of the Accident and Emergency Unit of the University College Hospital (UCH), Ibadan.

(The Nation, Saturday, October 18, 2014: pp.14-15.)

\section{Excerpt 11}

How hygienic are some of the foods we eat? The nation's current experience with the Ebola Virus Disease (EVD) has caused many people to be extra conscious about what they consume and to question the source of such foods and the hygienic condition in which such foods are prepared. Before the Ebola upsurge, not many people cared about the healthiness of some food items like suya, maize, plantain and others and the processes they were made to undergo.

Excerpt 12

(Nigerian Tribune, Sunday, October 12, 2014: pp. 12-13.)

For residents of Onitsha, the commercial nerve centre of the South Eastern part of the country, these are not the best of times. Reason; the rising occurrence of collapsed buildings in the city has unsettled many residents who are not sure of which building will cave in the next time.

(Vanguard, Wednesday, June11, 2014: pp. 56-57.)

Addressing the Issue (AI): This element is the nucleus of the article. It is the element around which the feature article is centred. It indicates the fact that there exists an issue that has to be discussed, which may be social, political or economic in nature. Facts and statistics usually characterize this segment of the feature article. These are captured in excerpts 13-16 


\section{Excerpt 13}

Welcome to the world of traditional birth attendants, whom the registrar of the Lagos State traditional medicine board, Dr. Bodurin Oluwa, says currently account for up to about 60 per cent deliveries in the state. Technological and health advancements notwithstanding, the majority of deliveries in developing countries like Nigeria don't take place in registered hospitals and are handled by trained/untrained attendants. According to the World Health Organisation, these TBAs remain an integral part of the Nigerian existence as this profession has been handed over from one generation to another.

(The Punch, Thursday, June19, 2014: pp. 28-29.)

\section{Excerpt 14}

"The weeks leading to the hike were pretty hectic," he said. "I was spending hours in front of the system shooting emails to potential media partners and also calling folks in Lagos whose support was critical to the success of the climb. It didn't help that I was based in Dar es Salaam at that point." But climbing Mount Kilimanjaro is an exhausting task, which tasks the mind as well as the body. Mount Kilimanjaro is generally referred to as everyman's Everest because out of the seven great summits, it is considered the easiest to climb without oxygen and other specialized mountain climbing gears. Usually it costs about 3,000 dollars to climb Kilimanjaro, but with a guide he had a relationship with, the party paid less.

(The Nation, Sunday, October 12, 2014: pp.19-21.)

\section{Excerpt 15}

According to him, the medications prescribed for him at the hospital are expensive and he could not afford to buy some 
of the drugs. The situation made his condition worse and he became an eyesore at the hospital having stayed far more than necessary. At a time when he felt that all hopes were lost, thinking that he had been forgotten, God, however sent him a helper and he breathed an air of relief when former Deputy Governor of Osun State and a one-time Chairman, Senate Committee on Finance and Appropriation, Chief Iyiola Omisore, visited the hospital and paid of his hospital bills and those of several other patients receiving treatment at the hospital.

(Nigerian Tribune, Friday January 24, 2014. p. 38.)

\section{Excerpt 16}

But Nicola, 38, first noticed something was wrong shortly after Connie started school. Her daughter had always been ahead of her years, learning to read and write while still at home. At three, she was completing 50- piece jigsaws, as she constantly encouraged her mother to read to her, and surprised nursery staff by how quickly she took to the books they were giving her. But within a few weeks of starting primary school, her behaviour suddenly changed.

(Vanguard, Saturday, October 11, 2014: p.38.)

Proffering a Solution (PS): This element specifies the writer's suggested solution(s) to the issue being discussed. It always comes towards the end or at the end of the feature article. This is illustrated below:

\section{Excerpt 17}

However, some of the complications can be prevented with prompt care. According to experts, delaying the first bath, 
increasing environmental temperature and covering the baby's head are part of the thermal care for preterm babies.

(The Punch, Thursday, May 22, 2014: pp.26-27.)

Excerpt 18

He advised parents to make the necessary sacrifice to spend time and train their children themselves instead of leaving the responsibility to others. "Their primary assignment as parents is the children and the family. Maids should not bring up children, it's not their job. It's the parents' duty. If you know you won't have time and would rather focus on your career, then don't have a family. It's not by force!" he said.

(The Nation, Saturday, October 25, 2014: p. 48.)

\section{Excerpt 19}

The lawmaker also appealed to both the State Governor and the Commissioner of Police to establish a police post in the community or patrol the area constantly so as to put an end to criminality there.

The State Police Commissioner, Mr Hycient Dagala.... suggested that the best way to solve the problem was to go back to history and see how the issue of grazing route could be revisited, pointing out that since all land belonged to government, government could use its authority to enforce strict rules on grazing areas and possibly revitalize them.

(Nigerian Tribune, Sunday, October 12, 2014: p.19)

Excerpt 20

He has been offered a bone marrow transplant but this, at best, may only slowdown the disease. His parents are now pinning their hope on an experimental enzyme replacement therapy being pioneered at the San Raffaele Clinic in Milan. 
(Vanguard, Saturday, October 11, 2014: pp. 38-39.)

Moral lesson (ML): This element always comes at the end of the article. It usually suggests a lesson that can be learnt from the issue being discussed. The following excerpts buttress this:

Excerpt 21

"At the risk of saying what is trite," he said," we need to keep pushing outside of our comfort zones; you learn a great deal about yourself outside of your zone of comfort. The thing about risk taking and adventure is that it provides a memory bank from which we can draw strength from, during subsequent encounters where you need to take more risk. It sort of reinforced for me the risk-return trade-off: the higher the risk; the higher the return.

(The Nation, Sunday, October 12, 2014: pp.19-21)

\section{Excerpt 22}

There should be feelings of hope and love for the patients and others in different terrible conditions of life. And, I believe a hospital should be a healing centre and not a money making enterprise hence the decision to pay the outstanding hospital bills which has made it impossible for some patients to leave the hospital months after they are healed.

...He said he had cultivated the habit of giving to the poor, having experienced the bad and the good sides of life in the past.

(Nigerian Tribune, Friday, January 24, 2014: p.38)

Table 2 below shows the distribution of these elements in the articles sampled. 
The distribution of elements in the texts

\begin{tabular}{|c|c|c|c|c|c|c|c|}
\hline $\begin{array}{l}\text { Newsp } \\
\text { aper }\end{array}$ & Date & $\begin{array}{l}\text { Headlin } \\
\text { e(H) }\end{array}$ & $\begin{array}{l}\text { Featur } \\
\text { e } \\
\text { Lead( } \\
\text { FL) }\end{array}$ & $\begin{array}{l}\text { Orie } \\
\text { ntati } \\
\text { on } \\
(0)\end{array}$ & $\begin{array}{l}\text { Addr } \\
\text { essin } \\
\mathrm{g} \text { the } \\
\text { Issue } \\
\text { (AI) }\end{array}$ & $\begin{array}{l}\text { Proffer } \\
\text { a } \\
\text { Solutiol } \\
\text { (PS) }\end{array}$ & $\begin{array}{l}\text { Mora } \\
\text { l } \\
\text { Lesso } \\
\text { n(ML } \\
\text { ) }\end{array}$ \\
\hline \multirow[t]{5}{*}{$\begin{array}{l}\text { The } \\
\text { Punch }\end{array}$} & $\begin{array}{l}\text { Sat., } \\
\text { April } \\
26, \\
2014\end{array}$ & Present & Nil & $\begin{array}{l}\text { Prese } \\
\text { nt }\end{array}$ & $\begin{array}{l}\text { Prese } \\
\text { nt }\end{array}$ & Nil & Nil \\
\hline & $\begin{array}{l}\text { Sat., } \\
\text { May } \\
10,2014\end{array}$ & Present & Present & $\begin{array}{l}\text { Prese } \\
\text { nt }\end{array}$ & $\begin{array}{l}\text { Prese } \\
\text { nt }\end{array}$ & Nil & Nil \\
\hline & $\begin{array}{l}\text { Thurs., } \\
\text { May 22, } \\
2014\end{array}$ & Present & Present & $\begin{array}{l}\text { Prese } \\
\mathrm{nt}\end{array}$ & $\begin{array}{l}\text { Prese } \\
\text { nt }\end{array}$ & $\begin{array}{l}\text { Presen } \\
\mathrm{t}\end{array}$ & Nil \\
\hline & $\begin{array}{l}\text { Thurs., } \\
\text { June 19, } \\
2014\end{array}$ & Present & Present & $\begin{array}{l}\text { Prese } \\
\text { nt }\end{array}$ & $\begin{array}{l}\text { Prese } \\
\text { nt }\end{array}$ & $\begin{array}{l}\text { Presen } \\
\mathrm{t}\end{array}$ & Nil \\
\hline & $\begin{array}{l}\text { Thurs., } \\
\text { July 31, } \\
2014\end{array}$ & Present & Present & $\begin{array}{l}\text { Prese } \\
\mathrm{nt}\end{array}$ & $\begin{array}{l}\text { Prese } \\
\mathrm{nt}\end{array}$ & Nil & Nil \\
\hline \multirow[t]{5}{*}{$\begin{array}{l}\text { The } \\
\text { Nation }\end{array}$} & $\begin{array}{l}\text { Sat., } \\
\text { Oct.11, } \\
2014\end{array}$ & Present & Present & $\begin{array}{l}\text { Prese } \\
\mathrm{nt}\end{array}$ & $\begin{array}{l}\text { Prese } \\
\text { nt }\end{array}$ & Nil & Nil \\
\hline & $\begin{array}{l}\text { Sun. } \\
\text { Oct. 12, } \\
2014\end{array}$ & Present & Nil & $\begin{array}{l}\text { Prese } \\
\text { nt }\end{array}$ & $\begin{array}{l}\text { Prese } \\
\text { nt }\end{array}$ & Nil & $\begin{array}{l}\text { Prese } \\
\mathrm{nt}\end{array}$ \\
\hline & $\begin{array}{l}\text { Sat. } \\
\text { Oct. 18, } \\
2014\end{array}$ & Present & Present & $\begin{array}{l}\text { Prese } \\
\mathrm{nt}\end{array}$ & $\begin{array}{l}\text { Prese } \\
\text { nt }\end{array}$ & Nil & Nil \\
\hline & $\begin{array}{l}\text { Sun.Oct } \\
.19, \\
2014\end{array}$ & Present & Present & $\begin{array}{l}\text { Prese } \\
\text { nt }\end{array}$ & $\begin{array}{l}\text { Prese } \\
\text { nt }\end{array}$ & Nil & Nil \\
\hline & $\begin{array}{l}\text { Sat. } \\
\text { Oct. 25, } \\
2014\end{array}$ & Present & Present & $\begin{array}{l}\text { Prese } \\
\mathrm{nt}\end{array}$ & $\begin{array}{l}\text { Prese } \\
\text { nt }\end{array}$ & $\begin{array}{l}\text { Presen } \\
\mathrm{t}\end{array}$ & Nil \\
\hline
\end{tabular}




\begin{tabular}{|c|c|c|c|c|c|c|c|}
\hline \multirow[t]{5}{*}{$\begin{array}{l}\text { Nigeria } \\
n \\
\text { Tribun } \\
e \\
\end{array}$} & $\begin{array}{l}\text { Fri. } \\
\text { Jan.24, } \\
2014\end{array}$ & Present & Nil & $\begin{array}{l}\text { Prese } \\
\text { nt }\end{array}$ & $\begin{array}{l}\text { Prese } \\
\text { nt }\end{array}$ & $\begin{array}{l}\text { Presen } \\
\mathrm{t}\end{array}$ & $\begin{array}{l}\text { Prese } \\
\text { nt }\end{array}$ \\
\hline & $\begin{array}{l}\text { Sun. } \\
\text { June } 1, \\
2014\end{array}$ & Present & Present & $\begin{array}{l}\text { Prese } \\
\text { nt }\end{array}$ & $\begin{array}{l}\text { Prese } \\
\mathrm{nt}\end{array}$ & $\begin{array}{l}\text { Presen } \\
\mathrm{t}\end{array}$ & Nil \\
\hline & $\begin{array}{l}\text { Sat. } \\
\text { Oct. 11, } \\
2014\end{array}$ & Present & Present & $\begin{array}{l}\text { Prese } \\
\text { nt }\end{array}$ & $\begin{array}{l}\text { Prese } \\
\text { nt }\end{array}$ & $\begin{array}{l}\text { Presen } \\
\mathrm{t}\end{array}$ & Nil \\
\hline & $\begin{array}{l}\text { Sun. } \\
\text { Oct., } \\
12, \\
2014\end{array}$ & Present & Present & $\begin{array}{l}\text { Prese } \\
\text { nt }\end{array}$ & $\begin{array}{l}\text { Prese } \\
\text { nt }\end{array}$ & $\begin{array}{l}\text { Presen } \\
\mathrm{t}\end{array}$ & Nil \\
\hline & $\begin{array}{l}\text { Sun. } \\
\text { Oct. 12, } \\
2014\end{array}$ & Present & Present & $\begin{array}{l}\text { Prese } \\
\text { nt }\end{array}$ & $\begin{array}{l}\text { Prese } \\
\text { nt }\end{array}$ & Nil & Nil \\
\hline \multirow[t]{5}{*}{$\begin{array}{l}\text { Vangu } \\
\text { ard }\end{array}$} & $\begin{array}{l}\text { Wed. } \\
\text { June 11, } \\
2014\end{array}$ & Present & Nil & $\begin{array}{l}\text { Prese } \\
\text { nt }\end{array}$ & $\begin{array}{l}\text { Prese } \\
\text { nt }\end{array}$ & $\begin{array}{l}\text { Presen } \\
\mathrm{t}\end{array}$ & Nil \\
\hline & $\begin{array}{l}\text { Wed. } \\
\text { June 11, } \\
2014\end{array}$ & Present & Nil & $\begin{array}{l}\text { Prese } \\
\text { nt }\end{array}$ & $\begin{array}{l}\text { Prese } \\
\text { nt }\end{array}$ & Nil & Nil \\
\hline & $\begin{array}{l}\text { Sat. } \\
\text { Oct. 11, } \\
2014\end{array}$ & Present & Nil & $\begin{array}{l}\text { Prese } \\
\text { nt }\end{array}$ & $\begin{array}{l}\text { Prese } \\
\text { nt }\end{array}$ & $\begin{array}{l}\text { Presen } \\
t\end{array}$ & Nil \\
\hline & $\begin{array}{l}\text { Wed. } \\
\text { Oct. 15, } \\
2014\end{array}$ & Present & Present & $\begin{array}{l}\text { Prese } \\
\text { nt }\end{array}$ & $\begin{array}{l}\text { Prese } \\
\text { nt }\end{array}$ & Nil & Nil \\
\hline & $\begin{array}{l}\text { Sat. } \\
\text { Oct. } 18,\end{array}$ & Present & Nil & $\begin{array}{l}\text { Prese } \\
\text { nt }\end{array}$ & $\begin{array}{l}\text { Prese } \\
\text { nt }\end{array}$ & Nil & Nil \\
\hline
\end{tabular}




\begin{tabular}{|l|l|l|l|l|l|l|l|}
\hline & 2014 & & & & & & \\
\hline $\begin{array}{l}\text { Percent } \\
\text { age }\end{array}$ & & $100 \%$ & $65 \%$ & $\begin{array}{l}100 \\
\%\end{array}$ & $100 \%$ & $45 \%$ & $10 \%$ \\
\hline
\end{tabular}

The foregoing analysis could be summarised thus:

(a) Headline $(\mathbf{H})$ : This element is obligatory. It occurred in all the texts analysed.

(b) Feature Lead (FL): This is an optional element. It occurred in 65 per cent of all the analysed texts. In the articles where the element did not occur, it was observed that the Orientation (O) came immediately after the Headline $(\mathrm{H})$. It occurred in 80 per cent of the analysed texts in The Punch, The Nation and Nigerian Tribune. It, however, occurred in 20 per cent of the texts in Vanguard.

(c) Orientation $(\mathbf{O})$ : Like the element $(\mathrm{H})$, this is also obligatory. It appeared in all the analysed texts.

(d) Addressing the Issue (AI): This also occurred in all the analysed text; thus, it is an obligatory element.

(e) Proffering a Solution (PS): This element occurred in 45 per cent of all the analysed texts; it is optional. Where (PS) did not occur, the article ended with the discussion of the issue (AI). It occurred in 40 per cent of the texts in The Punch, in 20 per cent of the texts in The Nation, in 80 per cent of the texts in Nigerian Tribune and in 40 per cent of the texts in Vanguard.

(f) Moral Lesson (ML): This is an optional element. It occurred in 10 per cent of all the analysed texts. It did not occur at all in the texts in The Punch and Vanguard but occurred in 20 per cent of the texts in The Nation and Nigerian Tribune. 


\section{Sequence of Obligatory and Optional Elements}

Three (3) obligatory elements were identified in the analysed texts: Headline (H), Orientation (O) and Addressing the Issue (AI). Also, three optional elements were identified: Feature Lead (FL), Proffering a Solution (PS) and Moral Lesson (ML).

\section{Obligatory elements: $[\mathrm{H}]^{\wedge}[\mathrm{O}]^{\wedge}[\mathrm{AI}]$}

The caret $\left({ }^{\wedge}\right)$ shows the sequence of the elements, while the square brackets [ ] indicate restraint on sequence. These elements appear in this order in the twenty (20) feature articles that were analysed. They form the nucleus of these articles, that is, they are essential to the creation of the articles.

\section{Optional elements: $(\mathrm{FL})^{\wedge}(\mathrm{PS}) .(\mathrm{ML})$}

The round brackets ( ) show optionality of the elements, while the dot (.) means more than one option in sequence. That is, the occurrence of these elements varied in the analysed texts. The sequence of the optional elements whenever they occur is the Feature Lead (FL), followed by either Proffering a Solution (PS) or Moral Lesson (ML). In a few cases, the two might occur together. In the texts where these elements were not found, the texts were still found to be meaningful. Although they contribute to the development of the texts, they are not essential to the creation of the texts.

\section{GSP of Feature Articles in Nigerian Newspapers}

Hasan (1984) describes the Generic Structure Potential (GSP) of a particular genre as a statement of the structural resources available within a given genre. A GSP is thus an abstract theoretical notion (Halliday and Hasan, 1989) that expresses the total range of optional, iterative and obligatory elements and their order in such a way that we exhaust the possibilities of text structure for every text that can be appropriate to the Contextual Configuration of that text. 
Three obligatory structural elements were identified in $100 \%$ of the feature articles in the samples studied. There were also three optional elements. The GSP for feature articles in Nigerian newspapers can, therefore, be catalogued as:

\section{$\mathbf{H}^{\wedge}\left[(\mathbf{F L})^{\wedge} \mathbf{O}^{\wedge}\right]\left[\mathbf{A I} \mathbf{I}^{\wedge}(\mathbf{P S}) .(\mathbf{M L})\right]$}

This GSP is a condensed statement suggesting that a Nigerian newspaper feature article typically has a headline that may or may not be followed by a feature lead. Next is an orientation, and then an issue to be addressed. A suggested solution or a moral lesson is the last element.

\section{Conclusion}

This paper tried to establish the generic structure of feature articles in four Nigerian newspapers: The Punch, The Nation, Nigerian Tribune and Vanguard. The analysis revealed three obligatory elements: Headline, Orientation and Addressing the Issue; and three optional elements: Feature Lead, Proffering a Solution and Moral Lesson. A Nigerian newspaper feature article typically starts with a headline that may or may not be followed by a feature lead. Feature articles constitute an important sub-genre of the newspaper and the writers of this sub-genre have mastered the art such that one can conveniently identify a feature article as distinct from other sub-genres of Nigerian newspapers.

\section{Adesina B. Sunday \\ \&}

Olufunke O. Fagunleka

Department of English

University of Ibadan, Ibadan

sinadaybuk@gmail.com 


\section{References}

\section{Primary Sources}

Adebayo, F. Born too soon in hospitals without incubators. The Punch. May 22, 2014:26-27.

Adeoye, D. Day Omisore visited the sick. Nigerian Tribune. January 24, 2014:38.

Adeoye, G. Nigeria joins countries with rare mineral water source. The Punch. April 26, 2014:24-25.

Adewakun, A. and Makinde, T. Beware! Hi-tech robbers on the prowl. Nigerian Tribune. June 1, 2014:13-14.

Agbro, J. For Down syndrome they climbed Kilimanjaro. The Nation. October 12, 2014:20-21.

Ajiboye, S. and Duru, I. At the mercy of vandals. The Nation. October 11, 2014: 17-18, 47.

Alaka, G. Absentee husbands: the pains, the frustration. The Nation. October 19, 2014:20-21.

Anguish of parents who passed on fatal gene to their children. Vanguard. October 11, 2014:38-39.

Augoye, J. Harvest of births in dirty maternity homes. The Punch. June 19, 2014:28-29.

Babajide, J. The children of Benue....Beaten, raped and killed. Nigerian Tribune. October 12, 2014:14,19.

Boko Haram: 136 refugees use one toilet. Saturday Tribune. October 11, 2014:5.

Death of a Voodoo President heavily backed by USA. Vanguard. October 18, 2014:42.

Dumo, E. Exposed at school, vulnerable at home. The Punch. May 10, 2014:20-21.

Famutimi, T. Unemployed Nigerian pilots turn office assistants, estate agents. The Punch. July 31, 2014:26-27. 
Nwabueze, O. Frequent building collapse: fear grips Onitsha residents. Vanguard. June 11, 2014:56-57.

Oladele, B. Ibadan fire: relations turn hospitals into 'prayer house' as victims die daily. The Nation. October 18, 2014:14-15.

Olatunji, D. Welcome to Arepo where vandals are kings. Vanguard. June 11, 2014:57.

Omonubi, K. and Kumolu, C. War on terror: disturbing tales of conspiracy, sabotage. Vanguard. October 15, 2014:38-39.

Saduwa, P. et al. Too busy for the family. The Nation. October 25,2014:17-18; 47-48.

Solaja, G. When touching is inevitable: edibles that may question hygiene. Nigerian Tribune. October 12, 2014:12-13.

\section{Secondary Sources}

Afful, I. 2012. A comparative analysis of titles of feature articles in the Daily Graphic and Ghanaian Times. Retrieved January 3, 2015 from https://www.academia.edu/.../

Ansary, H. and Babaii, E. 2004. The generic integrity of newspaper editorials: a systemic functional perspective. Asian EFL Journal 6: $1-28$.

Ansary, H. and Babaii, E. 2009. A cross-cultural analysis of English newspaper editorials: a systemic-functional view of text for contrastive rhetoric research. RELC Journal 40.2:211-248.

Bolivar, A. 1994.The structure of newspaper editorials. Advances in written text analysis. R. M. Coulthard. Ed. London: Routledge. 276-94.

Bruce, I. 2009. Results section in sociology and organic chemistry articles: a genre analysis. English for Specific Purposes 28:105124. 
Bula, F. 1996. No news here: the feature genre, newspapers' "other" storytelling form. Project, School of Communication, Simon Fraser University.

Garrison, B. 2004.Professional feature writing. 4th ed. New Jersey:

Lawrence Erlbaum Associates.

Ghadessy, M. 1993. On the nature of written business communication.

Register Analysis: theory and practice. M. Ghadessy. Ed. London: Pinter Publishers. 149-164.

Halliday, M.A.K. 1985. Dimensions of discourse analysis and grammar.

Handbook of discourse analysis. T. van Dijk. Ed. London: Academic Press. 29-56.

Halliday, M.A.K. and Hasan, R. 1985. Language, context and text: aspects of language in a social-semiotic perspective. Victoria: Deakin University.

Halliday, M.A.K. and Hasan, R.1989. Language, context and text: aspects of language in a social-semiotic perspective. $2^{\text {nd }}$ ed. Oxford: Oxford University Press.

Hasan, R. 1984. The nursery tale as a genre. Nottingham Linguistic Circular 13:71-102.

Henry, A. and Roseberry, R. 1997. An investigation of the function, strategies and linguistic features of the introductions and conclusions of essays. System 25:479-495.

Katajamaki, H. and Koskela, M. 2007. The rhetorical structure of editorials in English, Swedish and Finnish business newspapers. Teoksessa Proceedings of the $5^{\text {th }}$ International Aelfe Conference: Prensas Universitarias de Zaragoza 215219. Retrieved July 28, 2014, from http://www.nic.fi/ hesuka/katajamakikoskela.pdf.

Media in Nigeria/Nigerian newspapers, radio and televisions. Retrieved January 2, 2015 from http:www.cometonigeria.com/...Nigeria/media... 
Odebunmi, A. 2007. The stylistics of religious electronic media advertisement in Nigeria. Style in religious communication in Nigeria. A. Odebunmi\& A. Babajide. Eds. Munchen: Lincom Europa. 1-26.

Ogungbe, E. O. 2012. Pragmatic acts in the news reports of some Nigerian newspapers. Ph.D Thesis, Department of English University of Ibadan.

Santosa, R. 2005. Register in English newspaper. Surakarta: Faculty of Letters and Fine Art, Sebelas Maret University.

Santosa, R. 2009. Genre in media discourse. Journal of Bahasa Sastradan Studi Amerika, English Department: Maret University. 1-23.

Shoukouhi, H. and Amin, F. 2010. A systemist 'verb transitivity' analysis of the Persian and English newspaper editorials: A focus on genre familiarity on EFL learner's reading comprehension. Journal of Language Teaching and Research1.4:387-396.

Steensen, S. 2009. What is feature journalism? $19^{\text {th }}$ Nordic Conference for Media and Communication Research, Karlstad.

Steensen, S.2010. Online feature journalism: a clash of discourses. Journalism Practice3.1:13-29.

Stephens, M. 1994.History of newspapers. Colliers encyclopedia.

Swales, J.M. 1990.Genre Analysis: English in academic and research setting. Cambridge: C.U.P. 